\title{
Pengembangan E-Modul Berbantu Kodular pada Smartphone untuk Meningkatkan Kemampuan Berpikir Kritis Matematis Siswa SMP
}

\author{
Tristi Ardita Rismayanti ${ }^{1}$, Nurul Anriani ${ }^{2}$, Sukirwan ${ }^{3}$ \\ 1,2,3 Jurusan Pendidikan Matematika, Fakultas Keguruan dan Ilmu Pendidikan, Universitas Sultan Ageng Tirtayasa, \\ J1. Ciwaru Raya, Cipare, Kec. Serang, Kota Serang, Banten 42117 \\ tristiarditary@gmail.com
}

\begin{abstract}
The purpose of this study is to develop and determine the feasibility of the critical thinking e-module. This research produces an e-module so that this research is development research $(\mathrm{R} \& \mathrm{D})$ with the research subjects of class VIII students of SMPN 1 Cikupa and mathematics teachers. The research method used is the ADDIE development model. Critical thinking e-module is made with quadrilateral and triangle material on android smartphone. The results of the study obtained that e-module was categorized as feasible based on the validity aspect through media expert tests and material experts with a percentage of $81 \%$, practical aspects through student response questionnaires with a percentage of $85 \%$ and teacher responses with a percentage of $83 \%$, and aspects of effectiveness based on a score of $\mathrm{n}$. -gain is 0.37 medium category. The increase in mathematical critical thinking skills obtained n-gain scores on the interpreting aspects (0.53), analyzing aspects $(0.22)$, evaluating aspects (0.49), and inference aspects (0.24). It was concluded that the codular-assisted e-module on an android smartphone is attractive and feasible to use and it is able to improve the mathematical critical thinking skills of junior high school students.
\end{abstract}

Keywords: e-module, kodular, smartphone, mathematical critical thinking

\begin{abstract}
Abstrak
Tujuan penelitian ini mengembangkan dan mengetahui kelayakan e-modul. Penelitian ini menghasilkan emodul sehingga penelitian ini merupakan penelitian pengembangan ( R \& D) dengan subjek penelitian siswa kelas VIII SMPN 1 Cikupa dan guru matematika. Metode penelitian yang digunakan adalah model pengembangan ADDIE. E-modul dibuat dengan materi segiempat dan segitiga pada smartphone android. Hasil penelitian diperoleh e-modul dengan kategori layak berdasarkan aspek kevalidan melalui uji ahli media dan ahli materi dengan persentase $81 \%$, aspek kepraktisan melalui angket respon siswa dengan persentase $85 \%$ dan respon guru dengan persentase $83 \%$, serta aspek keefektifan berdasarkan skor n-gain yakni 0,37 kategori sedang. Peningkatan kemampuan berpikir kritis matematis diperoleh skor n-gain pada aspek menginterpretasi (0.53), aspek menganalisis (0.22), aspek mengevaluasi (0.49), dan aspek menginferensi (0.24). Maka disimpulkan bahwa e-modul berbantu kodular pada smartphone android menarik dan layak digunakan serta mampu meningkatkan kemampuan berpikir kritis matematis siswa SMP.
\end{abstract}

Kata kunci: e-modul, kodular, smartphone, berpikir kritis matematis

Copyright (c) 2022 Tristi Ardita Rismayanti, Nurul Anriani, Sukirwan

$\square$ Corresponding author: Tristi Ardita Rismayanti

Email Address tristiarditary@gmail.com (Jl. Ciwaru Raya, Cipare, Kec. Serang, Kota Serang, Banten 42117)

Received 11 January 2022, Accepted 10 February 2022, Published 12 February 2022

\section{PENDAHULUAN}

Revolusi industri 4.0 merupakan perkembangan dunia abad 21 yang menuntut pemanfaatan teknologi informasi dan komunikasi dalam segala segi kehidupan termasuk proses pembelajaran (Agustina, 2019). Perkembangan dunia abad 21 dalam proses pembelajaran mengharuskan pemerintah untuk meningkatkan sumber daya manusia dengan kemampuan berpikir kritis, kreatif, kerjasama, komunikasi dan memecahkan masalah (Mardhiyah et al., 2021). Upaya yang dapat dilakukan untuk meningkatkan sumber daya manusia salah satunya dengan berfokus pada kemampuan berpikir kritis matematis yang dapat dikembangkan melalui pembelajaran matematika. Berpikir kritis matematis adalah kemampuan dasar yang penting dimiliki oleh siswa dalam pembelajaran matematika (Zulfa, 2019). Kemampuan berpikir kritis matematis dapat melatih siswa 
untuk pandai membaca situasi dari setiap masalah, mengevaluasi dan mengambil kesimpulan terhadap kondisi tertentu sehingga pengetahuan yang dibangun siswa semakin kuat dan tidak mudah terlupakan (Sari, 2019).

Pentingnya kemampuan berpikir kritis matematis siswa namun belum didukung dalam pembelajaran matematika. Hal tersebut terlihat dari jawaban siswa dalam mengerjakan soal tes kemampuan berpikir kritis matematis dimana siswa belum mampu menginterpretasi soal dengan menuliskan apa yang diketahui dan ditanyakan dengan tepat, siswa tidak mampu memberikan penjelasan yang logis sesuai materi, siswa kurang teliti dalam menjawab soal serta siswa tidak mampu memberikan kesimpulan yang tepat. Selain itu, hasil wawancara yang dilakukan dengan guru matematika menyebutkan bahwa kemampuan berpikir kritis matematis siswa masih rendah terlihat dari cara siswa menyelesaikan soal yang diberikan dan kurangnya keberanian siswa dalam menyatakan pendapat ataupun bertanya. Rendahnya kemampuan berpikir kritis matematis siswa salah satunya terjadi karena proses pembelajaran matematika yang berpusat pada guru (Ratnawati et al., 2020). Hal tersebut menyebabkan siswa bergantung pada guru dan buku teks sebagai pusat pembelajaran dalam penyampaian ilmu pengetahuan (Siamy et al., 2018). Penggunaan buku teks yang digunakan guru sebagai satu-satunya bahan ajar di berbagai sekolah hanya menyajikan soal rutin dan penyelesaiannya menggunakan rumus yang telah disajikan sehingga belum menuntun siswa untuk berpikir kritis matematis (Novtiar \& Aripin, 2017). Selain itu, penyajian buku teks yang dimiliki siswa juga cenderung monoton dan verbalistis sehingga siswa kesulitan dalam mempelajarinya (Madroji et al., 2019). Oleh karena itu, untuk mendukung meningkatnya kemampuan berpikir kritis matematis siswa harus didukung dengan bahan ajar yang sesuai.

Puspitasari (2019) menyatakan bahwa bahan ajar mandiri berupa media pembelajaran dapat digunakan untuk memperkaya pengalaman belajar siswa sehingga meningkatkan kemampuan berpikir kritis matematis siswa. Media pembelajaran telah berkembang seiring berkembangnya teknologi informasi dan komunikasi menjadi e-learning (Sari, 2015). Salah satu bentuk e-learning yang dapat dijadikan sebagai bahan ajar mandiri adalah e-modul. Hal tersebut didasari oleh pernyataan Dimhad (2014) bahwa e-modul dapat membantu siswa belajar secara mandiri dan merupakan bagian dari electronic based e-learning yang memanfaatkan kemajuan teknologi berupa perangkat elektronik dalam pembelajaran (Santosa et al., 2017).

E-modul merupakan transformasi dalam hal penyajian dari bentuk cetak ke dalam bentuk elektronik (Satriawati, 2015). Kelebihan e-modul dibandingkan dengan modul cetak adalah e-modul dapat dilengkapi dengan video, audio, animasi, dan fitur interaktif lainnya yang dapat dimainkan dan diputar ulang oleh siswa sehingga akan memperkaya pengalaman belajar siswa (Suarsana \& Mahayukti, 2013). E-modul juga memberikan pengalaman belajar mandiri kepada siswa sehingga siswa dapat belajar memecahkan masalah dengan caranya sendiri (Hamzah \& Mentari, 2017). Selain itu, penggunaan e-modul memberi kemudahan kepada guru dalam mengontrol materi ajar yang sesuai dengan tingkat kemampuan siswa serta proses pembelajaran tidak hanya dilakukan di dalam kelas, 
namun juga diluar kelas (Tsai et al., 2018). E-modul dapat diakses dan digunakan melalui alat elektronik seperti komputer, laptop, bahkan smartphone (Oktavia et al.). Hasil survei yang dilakukan Asosiasi Penyelenggara Internet Indonesia (APJII) tahun 2020 menunjukkan bahwa persentase pengguna perangkat elektronik terbanyak adalah smartphone (Maulida, 2020). Selain itu, pengguna smartphone juga didominasi oleh kalangan muda sehingga dapat dimanfaatkan dalam kegiatan pembelajaran (Sulisworo et al., 2014). Smartphone tentunya membutuhkan sistem operasi yang mendukung kecanggihan tersebut, hasil analisis situs web Global Stats tahun 2021 menunjukkan bahwa pengguna sistem operasi pada smartphone terbanyak dibandingkan sistem operasi lain adalah android. Hal tersebut dikarenakan, banyaknya aplikasi yang dapat diunduh dengan mudah oleh pengguna android karena sifatnya open source yang memberikan kebebasan bagi pengembang untuk mengembangkan aplikasi pada smartphone (Maiyana, 2018).

Aplikasi yang dikembangkan pada android tentunya membutuhkan alat pengembang aplikasi yang sesuai. Pengembangan aplikasi android dapat dilakukan dengan bahasa pemrograman dan tanpa bahasa pemrograman yaitu dengan website pengembang aplikasi yang tersedia di internet (Syarisma, 2020). Pengembangan aplikasi dengan bahasa pemrograman dirasa sulit dilakukan untuk pemula karena pengembang aplikasi perlu memahami dan menguasai bahasa pemrograman terlebih dahulu, sedangkan pengembangan aplikasi tanpa bahasa pemrograman dirasa cocok untuk pemula sebab pengembang yang tidak familiar dengan bahasa pemrograman tetap dapat mengembangkan aplikasi. Terdapat beberapa web pengembang aplikasi tanpa bahasa pemrograman pada android seperti Appypie, MIT App Inventor, dan Kodular yang masing-masing memiliki kelebihan dan kekurangan. Adapun pada penelitian ini digunakan web pengembang aplikasi Kodular menurut Ronaldo \& Ardoni (2020) kodular merupakan salah satu website pengembang aplikasi yang memungkinkan penggunanya untuk membuat aplikasi berbasis android dengan gratis dan dengan blok programming, sehingga penggunanya tidak perlu melakukan koding. Hasil penelitian yang dilakukan Pamungkas (2020) juga menunjukkan bahwa media pembelajaran yang dikembangkan dengan kodular lebih efektif digunakan dalam pembelajaran dikelas dibanding tanpa menggunakan media pembelajaran dengan kodular. Berdasarkan uraian diatas, peneliti bermaksud melakukan penelitian pengembangan berupa e-modul berbantu Kodular pada smartphone android untuk meningkatkan kemampuan berpikir kritis matematis yang layak digunakan dalam pembelajaran matematika.

\section{METODE}

Penelitian ini bertujuan untuk menghasilkan e-modul berpikir kritis berbantu Kodular pada smartphone android sehingga penelitian ini merupakan jenis penelitian dan pengembangan atau Research and Development (R\&D) dengan model pengembangan ADDIE. Model pengembangan ADDIE dikembangkan oleh Dick and Carry (1996) untuk menyusun sistem pembelajaran (Mulyatiningsih, 2008). Tahapan pengembangan ADDIE pada penelitian ini yaitu (1) Tahap analisis, menganalisis permasalahan pada pembelajaran sehingga perlu dilakukan pengembangan bahan ajar; 
(2) Tahap desain, merancang flowchart dan menyusun materi; (3) Tahap pengembangan, mengembangkan produk dan melakukan validasi ahli; (4) Tahap implementasi, menggunakan emodul yang telah dikembangkan pada proses pembelajaran di kelas; dan (5) Tahap evaluasi, melihat ketercapaian e-modul dan melakukan perbaikan.

Subjek penelitian ini adalah siswa kelas VIII SMP Negeri 1 Cikupa dan guru matematika. Instrumen pengumpulan data yang digunakan adalah pedoman wawancara untuk mengetahui permasalahan dalam pembelajaran, angket ahli media dan ahli materi untuk mengetahui kevalidan emodul, angket respon siswa dan guru untuk mengetahui kepraktisan e-modul, dan tes kemampuan berpikir kritis matematis untuk mengetahui keefektifan e-modul. Analisis data yang dilakukan pada penelitian ini untuk mendapatkan e-modul yang layak dan berkualitas yang memenuhi aspek kevalidan, kepraktisan, dan keefektifan (Prabowo et al., 2016). Jawaban responden pada instrumen angket dianalisis menggunakan rumus (Widoyoko, 2015).

$$
p=\frac{\text { skor total responden }}{\text { skor maksimum responden }} \times 100 \%
$$

Hasil perhitungan yang diperoleh kemudian dikelompokkan berdasarkan kriteria penilaian angket ahli media dan ahli materi, serta angket respon siswa guru. Kriteria penilaian kevalidan, dan kepraktisan dapat dilihat pada Tabel 1 dan 2.

Tabel 1. Kriteria Penilaian Kevalidan E-Modul (Sugiyono, 2016)

\begin{tabular}{|c|c|}
\hline Presentase & Kriteria \\
\hline $25 \%-43 \%$ & Tidak Valid \\
\hline $44 \%-62 \%$ & Kurang Valid \\
\hline $63 \%-81 \%$ & Valid \\
\hline $82 \%-100 \%$ & Sangat Valid \\
\hline
\end{tabular}

Tabel 2. Kriteria Penilaian Kepraktisan E-Modul (Widoyoko, 2014)

\begin{tabular}{|c|c|}
\hline Presentase & Kriteria \\
\hline $25 \%-43 \%$ & Tidak Valid \\
\hline $44 \%-62 \%$ & Kurang Valid \\
\hline $63 \%-81 \%$ & Valid \\
\hline $82 \%-100 \%$ & Sangat Valid \\
\hline
\end{tabular}

Hasil tes kemampuan berpikir kritis matematis dianalisis menggunakan normalized gain ( $n$ gain) dengan rumus (Hake, 1999).

$$
g=\frac{\text { skor }_{\text {posttest }}-\text { skor }_{\text {pretest }}}{\text { skor }_{\text {maks }}-\text { skor }_{\text {pretest }}}
$$

Hasil perhitungan yang diperoleh dengan rumus n-gain dikelompokkan dalam kategori interpretasi $n$-gain dapat dilihat pada Tabel 3. 
Tabel 3. Interpretasi n-gain

\begin{tabular}{|c|c|}
\hline Nilai Gain & Klasifikasi \\
\hline $\mathrm{g} \geq 0,7$ & Tinggi \\
\hline $0,7>\mathrm{g} \geq 0,3$ & Sedang \\
\hline $0,3>\mathrm{g}$ & Rendah \\
\hline
\end{tabular}

\section{HASIL DAN DISKUSI}

\section{Hasil Penelitian}

Pengembangan e-modul berpikir kritis berbantu Kodular pada smartphone menggunakan model pengembangan ADDIE dengan tahap Analysis (Analisis), Design (Desain), Development (Pengembangan), Implementation (Implementasi) dan Evaluation (Evaluasi). Seluruh tahapan penelitian pengembangan ini diuraikan secara rinci sebagai berikut.

\section{Tahap Analisis}

Tahap analisis dilakukan dengan analisis kebutuhan, analisis kurikulum, dan analisis karakteristik siswa. Hasil analisis diperoleh berdasarkan wawacara terhadap guru matematika. Hasil analisis kebutuhan menunjukkan bahwa bahan ajar yang digunakan belum melibatkan siswa dalam proses berpikir kritis matematis karena bahan ajar yang digunakan selama ini hanya sebatas buku teks dan penyajiannya cenderung membosankan dan kurang menarik bagi siswa.

Hasil analisis kurikulum diperoleh materi matematika yang akan disajikan pada e-modul berpikir kritis yaitu materi Segiempat dan Segitiga. (Sumiati \& Agustini, 2020) menyatakan bahwa materi Segiempat dan Segitiga merupakan salah satu materi matematika yang banyak diaplikasikan dalam kehidupan sehari-hari serta materi ini juga sebagai dasar dalam mempelajari bangun lainnya seperti balok, kubus, dan lainnya sehingga penting untuk dikuasai dan dipahami siswa.

Hasil analisis karakteristik siswa menunjukkan bahwa siswa diperbolehkan membawa smartphone dan kemampuan siswa dalam menggunakan smartphone juga sudah baik. Selain itu, kemampuan berpikir kritis matematis siswa SMP Negeri 1 Cikupa masih tergolong rendah, sehingga dapat disimpulkan bahwa pengembangan e-modul pada smartphone sangat diperlukan untuk meningkatkan kemampuan berpikir kritis matematis.

\section{Tahap Desain}

Tahap desain merupakan tahap merancang e-modul dengan membuat flowchart dan menyusun materi yang akan digunakan pada e-modul. Langkah pertama adalah merancang flowchart sesuai alur kerja pengguna dalam menggunakan e-modul yang dapat dilihat pada Gambar 1. Langkah selanjutnya adalah menentukan pengembang aplikasi yang digunakan yaitu Kodular. Kodular digunakan untuk mengembangkan e-modul berpikir kritis sesuai flowchart yang dibuat ke dalam bentuk aplikasi. Kemudian, menyusun materi Segiempat dan Segitiga dengan aspek berpikir kritis untuk digunakan pada e-modul. 


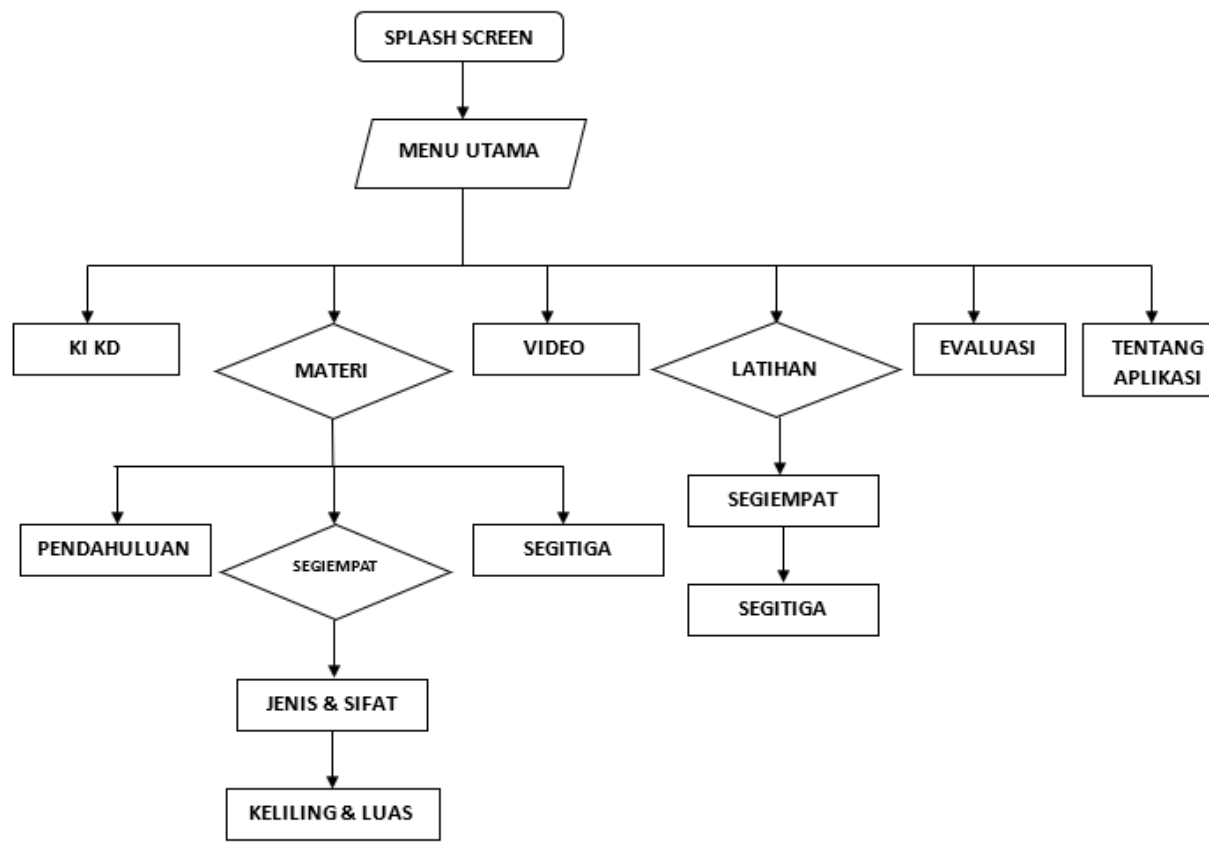

Gambar 1. Flowchart E-Modul

\section{Tahap Pengembangan}

Pembuatan e-modul dilakukan dengan menggunakan Kodular yang dapat diakses secara online dan gratis melalui www.kodular.io. Pemilihan teks, gambar, tema, dan animasi telah disesuaikan dengan karakteristik siswa SMP. E-modul dapat dioperasikan pada smartphone android yang dapat dipasang dengan mudah oleh siswa. Tampilan e-modul berisi splash screen dan menu KIKD, materi, video, latihan, evaluasi, dan tentang aplikasi. Menu materi menggunakan Liveworksheet yang berisi berbagai kegiatan sesuai aspek berpikir kritis dan kegiatannya langsung dapat dikerjakan oleh siswa. Menu latihan dan evaluasi berisi soal-soal high order thinking skill (HOTS) dan menggunakan Google Formulir untuk mengumpulkan jawabannya. Berikut disajikan tampilan pada e-modul pada Gambar 2, Gambar 3, dan Gambar 4.

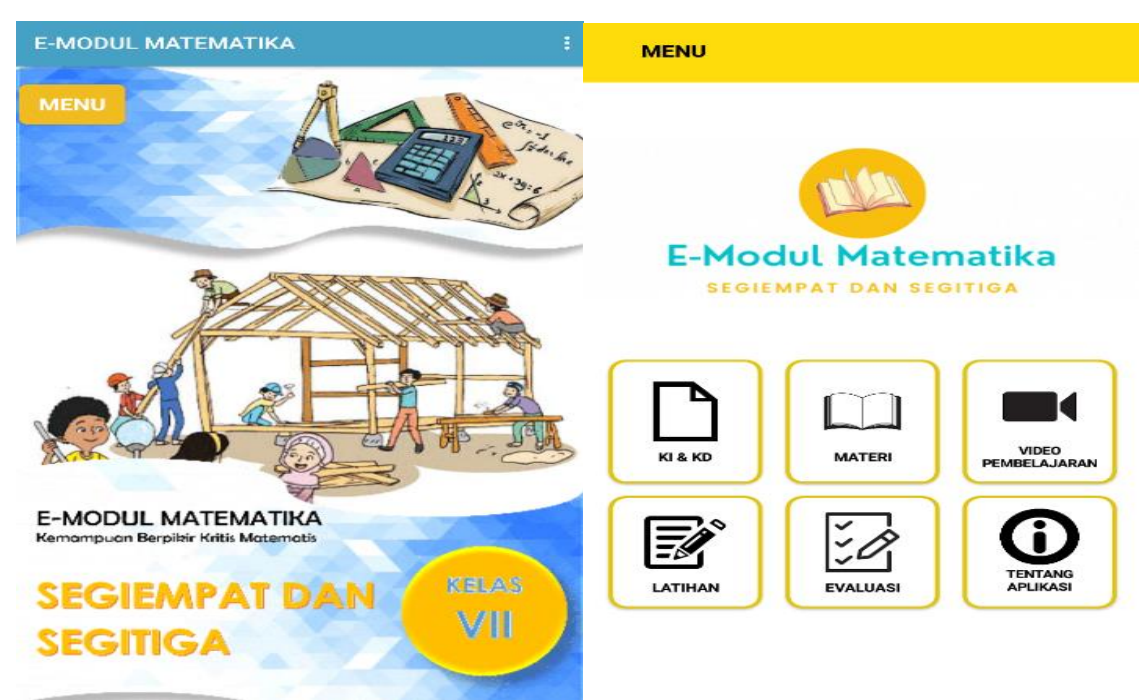

Gambar 2. Splash Screen dan Tampilan Menu E-Modul 


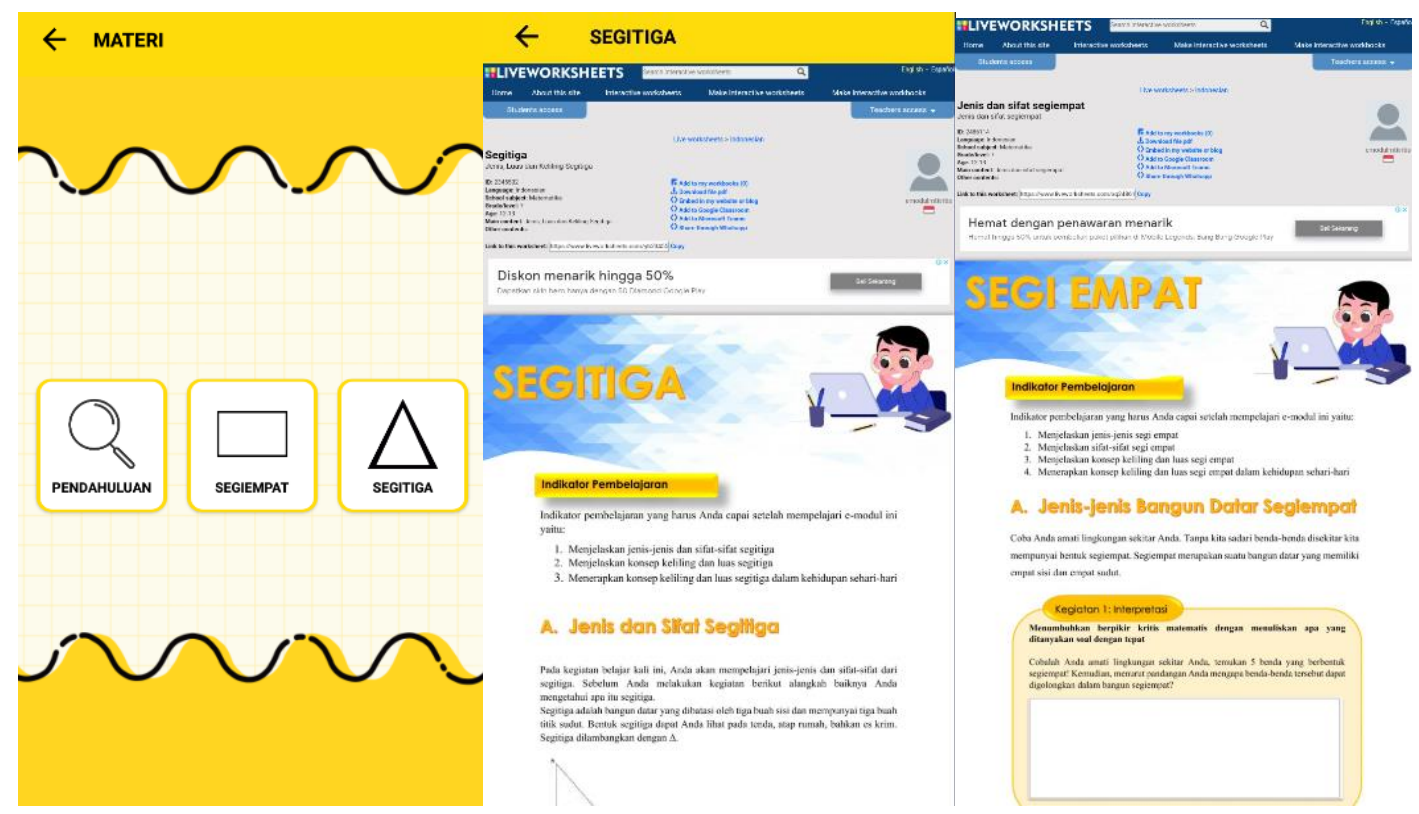

Gambar 3. Menu Materi

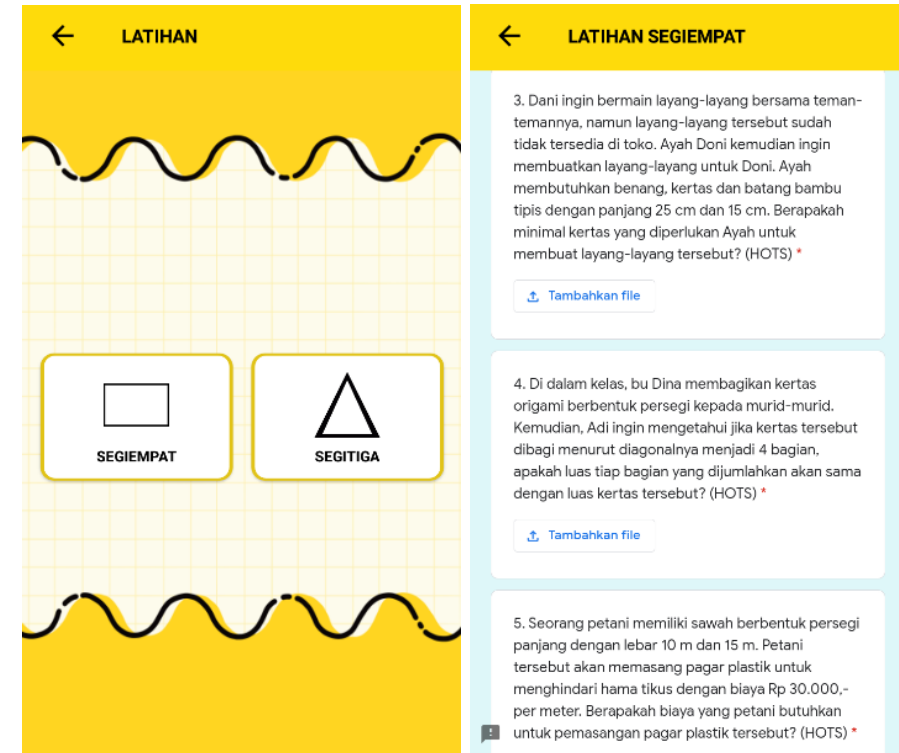

\section{$\leftarrow$ EVALUASI \\ 1. Keliling suatu persegi panjang $28 \mathrm{~cm}$. Jika panjangnya $2 \mathrm{~cm}$ lebih dari lebarnya. Tentukan luas persegi panjang tersebut! (HOTS) *

$$
\pm \text { Tambahkan file }
$$

2. Rumah Pak Joni mempunyai taman di depan rumahnya berbentuk persegi dengan ukuran panjang $90 \mathrm{~m}$. Taman tersebut akan dipasang pagar dengan biaya Rp 100.000,- per meter. Berapakah biaya yang diperlukan Pak Joni untuk memasang pagar tersebut? (HOTS) *

$$
\uparrow \text { Tambahkan file }
$$

3. Diketahui luas belahketupat $240 \mathrm{~cm} 2$ dan panjang salah satu diagonalnya $30 \mathrm{~cm}$. Keliling belahketupat tersebut? (HOTS)

\lrcorner Tambahkan file

Gambar 4. Menu Latihan dan Evaluasi

E-modul yang telah dikembangkan kemudian dilakukan validasi ahli media dan ahli materi untuk mendapatkan kevalidan e-modul. Berikut disajikan validitas ahli materi dan ahli media pada Tabel 4 dan Tabel 5.

Tabel 4. Validitas Ahli Media

\begin{tabular}{|c|l|c|c|}
\hline No. & \multicolumn{1}{|c|}{ Aspek } & Persentase & Kategori \\
\hline 1. & Desain & $78 \%$ & Baik \\
\hline 2. & Pengembangan & $80 \%$ & Baik \\
\hline 3. & Kegrafikan & $85 \%$ & Sangat Baik \\
\hline \multicolumn{2}{|c|}{ Total } & $\mathbf{8 1 \%}$ & Sangat Baik \\
\hline
\end{tabular}


Tabel 5. Validitas Ahli Materi

\begin{tabular}{|c|l|c|c|}
\hline No. & \multicolumn{1}{|c|}{ Aspek } & Persentase & Kategori \\
\hline 1. & Penyajian Materi & $83 \%$ & Sangat Baik \\
\hline 2. & Penyajian Soal & $80 \%$ & Baik \\
\hline 3. & Kemampuan Berpikir Kritis Matematis & $80 \%$ & Baik \\
\hline 4. & Kebahasaan Total & $80 \%$ & Baik \\
\hline \multicolumn{2}{|c|}{ Tot } & $\mathbf{8 1 \%}$ & Sangat Baik \\
\hline
\end{tabular}

Hasil validasi ahli media dan ahli materi menunjukkan persentase $81 \%$ dengan kategori sangat baik yang mana dapat disimpulkan bahwa e-modul valid dari segi media dan materi untuk digunakan. Terdapat beberapa saran yang diberikan validator ahli yaitu soal yang disajikan lebih baik menggunakan soal HOTS dan penyajian kegiatan pada materi lebih disesuaikan kembali dengan aspek berpikir kritis.

\section{Tahap Implementasi}

Tahap impelementasi dilakukan uji coba di kelas VIII D sebanyak 20 siswa. Proses pembelajaran dilakukan dengan menggunakan e-modul. Hasil yang diperoleh pada tahap ini untuk mengetahui keefektifan e-modul yang digunakan dalam proses pembelajaran apakah terdapat peningkatan hasil tes kemampuan berpikir kritis matematis sebelum menggunakan e-modul dan setelah menggunakannya serta kepraktisan e-modul. Berikut disajikan skor $n$-gain tes pretes-posttest kemampuan berpikir kritis matematis pada Tabel 6.

Tabel 6. Hasil N-gain tiap Aspek

\begin{tabular}{|c|l|c|c|c|c|}
\hline No. & \multicolumn{1}{|c|}{ Aspek } & Pretes & Posttes & $\begin{array}{c}\text { Normalized } \\
\text { Gain }\end{array}$ & Interpretasi \\
\hline 1. & Menginterpretasi & 41 & 77 & 0,53 & Sedang \\
\hline 2. & Menganalisis & 47 & 59 & 0,22 & Rendah \\
\hline 3. & Mengevaluasi & 53 & 76 & 0,49 & Sedang \\
\hline 4. & Menginferensi & 20 & 40 & 0,24 & Rendah \\
\hline \multicolumn{4}{|c|}{ Rata-rata } & $\mathbf{0 , 3 7}$ & Sedang \\
\hline
\end{tabular}

Hasil n-gain menunjukkan rata-rata skor 0,37 dengan interpretasi sedang dan terdapat 8 siswa pada klasifikasi rendah, 11 siswa pada klasifikasi sedang, dan 1 siswa pada klasifikasi tinggi. Setelah siswa melakukan pembelajaran dengan e-modul dan mengerjakan soal pretes-posttes, siswa dan guru mengisi angket respon terhadap kepraktisan e-modul dalam proses pembelajaran. Hasil kepraktisan tersebut disajikan pada Tabel 7 dan Tabel 8.

Tabel 7. Hasil Penilaian Respon Siswa

\begin{tabular}{|c|l|c|c|}
\hline No. & \multicolumn{1}{|c|}{ Aspek } & Persentase & Kategori \\
\hline 1. & Isi & $83 \%$ & Sangat Praktis \\
\hline 2. & Tampilan & $85 \%$ & Sangat Praktis \\
\hline 3. & Bahasa & $88 \%$ & Sangat Praktis \\
\hline \multicolumn{2}{r}{ Total } & $\mathbf{8 5 \%}$ & Sangat Praktis \\
\hline
\end{tabular}


Tabel 8. Hasil Penilaian Respon Guru

\begin{tabular}{|c|c|c|c|}
\hline No. & Aspek & Persentase & Kategori \\
\hline 1. & Materi & $82 \%$ & Sangat Praktis \\
\hline 2. & Media & $84 \%$ & Sangat Praktis \\
\hline \multicolumn{2}{|c|}{ Total } & $\mathbf{8 3 \%}$ & Sangat Praktis \\
\hline
\end{tabular}

Hasil kepraktisan berdasarkan penilaian angket respon guru dan respon siswa menunjukkan rata-rata persentase $84 \%$ dengan kategori sangat praktis yang berarti bahwa e-modul praktis digunakan dalam proses pembelajaran matematika.

\section{Tahap Evaluasi}

Tahap evaluasi dilakukan dengan menerima saran dan masukan yang diberikan validator ahli, guru, dan siswa terhadap e-modul yang dikembangkan. E-modul memperoleh presentase kevalidan $81 \%$ termasuk kategori sangat baik, presentase kepraktisan $84 \%$ termasuk kategori sangat praktis, dan skor $n$-gain diperoleh 0,37 termasuk interpretasi sedang yang menunjukkan bahwa efektif untuk digunakan sehingga berdasarkan aspek kevalidan, kepraktisan, dan keefektifan e-modul telah layak digunakan dan sesuai dengan ketercapaian e-modul.

\section{Diskusi}

Hasil penelitian menunjukkan bahwa e-modul yang dikembangkan dengan model ADDIE valid berdasarkan uji ahli media dan ahli materi, praktis berdasarkan uji respon siswa dan guru, dan efektif berdasarkan skor $n$-gain kemampuan berpikir kritis matematis siswa dalam menggunakan e-modul pada kegiatan pembelajaran. Kelayakan e-modul menunjukkan bahwa e-modul dapat digunakan siswa sebagai bahan ajar yang memberikan pengalaman belajar yang baru dan tidak membosankan karena penyajian materi yang berbeda dari bahan ajar lainnya yakni lebih menarik dan interaktif. Penyajian materi berisi berbagai kegiatan yang dapat langsung dikerjakan siswa pada kotak jawaban yang telah disediakan serta dilengkapi dengan gambar dan animasi yang memunculkan kemenarikan bagi siswa. Selain itu, penyajian e-modul pada smartphone yang rata-rata dimiliki siswa di era teknologi ini memberikan kemudahan bagi siswa untuk dapat belajar dimana pun dan kapan pun (Laili et al., 2019). E-modul juga dilengkapi menu latihan dan evaluasi yang berisi soal-soal HOTS sehingga siswa aktif berinteraksi dengan materi pada e-modul.

E-modul memiliki peran penting dalam pembelajaran yaitu membantu guru menjelaskan materi yang akan dijelaskan sebab e-modul mengacu pada tujuan pembelajaran yang ditetapkan, relevan dan sesuai dengan rencana pelaksanaan pembelajaran (RPP), dilengkapi dengan materi pembelajaran, petunjuk penggunaan, latihan, dan evaluasi, serta penyajiannya menarik bagi siswa. Penggunaan emodul pada smartphone dapat mengalihkan perhatian siswa kepada konten-konten pembelajaran yang lebih bermanfaat sehingga memberikan solusi bagi guru untuk menjawab tantangan terhadap kemajuan teknologi dan informasi dalam dunia pendidikan. E-modul yang disajikan pada smartphone juga membantu guru melakukan pembelajaran ditempat yang berbeda dengan siswa dan membantu siswa belajar mandiri dalam mengukur tingkat penguasaan serta pemahaman siswa terhadap materi 
ajar untuk mencapai tujuan pembelajaran atau target yang telah ditetapkan yaitu memahami dan menguasai materi segiempat dan segitiga serta menyelesaikan permasalahan sehari-hari terkait materi dan meningkatkan kemampuan berpikir kritis matematis.

\section{KESIMPULAN}

Berdasarkan hasil penelitian yang telah diperoleh pengembangan e-modul pada smartphone dilakukan dengan model pengembangan ADDIE yaitu: a) Tahap analisis, mengidentifikasi masalah yang dihadapi siswa terkait bahan ajar; b) Tahap desian, membuat flowchart, storyboard, dan penyusunan materi; c) Tahap pengembangan, mengembangkan e-modul dan melakukan validasi ahli; d) Tahap implementasi, melakukan ujicoba e-modul kepada siswa dan guru; e) Tahap evaluasi, melakukan penyempurnaan e-modul berdasarkan saran ahli, guru, dan siswa.

E-modul dinyatakan layak berdasarkan aspek kevalidan berdasarkan uji ahli media dan ahli materi diperoleh persentase $81 \%$ dengan kategori sangat baik, aspek kepraktisan berdasarkan respon guru dengan persentase $84 \%$ dengan kategori sangat praktis dan respon siswa dengan persentase $85 \%$ dengan kategori sangat praktis, aspek keefektifan berdasarkan skor n-gain 0,37 dengan klasifikasi sedang sehingga e-modul layak dan menarik untuk digunakan.

\section{UCAPAN TERIMA KASIH}

Peneliti berterima kasih kepada Dosen Pembimbing, Guru Matematika dan siswa kelas VIII SMP Negeri 1 Cikupa, dan semua pihak yang telah membantu dalam pelaksanaan dan tercapainya penelitian ini sehingga terlaksana dengan baik.

\section{REFERENSI}

Agustina, I. (2019). Pentingnya Berpikir Kritis dalam Pembelajaran Matematika di Era Revolusi Industri 4.0. Universitas Negeri Medan.

Global Stats. (2021). Mobile Operating System Market Share Indonesia. Tersedia pada https://gs.statcounter.com/os-market-share/mobile/indonesia. Diakses pada tanggal 27 April 2021.

Hake, R. R. (1999). Analyzing Change/Gain Scores. American Educational Research Association's Division Measurement and Research Methodology, 1-4.

Hamzah, I., \& Mentari, S. (2017). Development of Accounting E-Module to Support the Scientific Approach of Students Grade X Vocational High School. Journal of Accounting and Business Education, 2(1), 78-88. https://doi.org/10.26675/jabe.v1i1.9751

Laili, I., Ganefri, \& Usmeldi. (2019). Efektivitas Pengembangan E-Modul Project Based Learning pada Mata Pelajaran Instalasi. Jurnal Imiah Pendidikan Dan Pembelajaran, 3(3), 306-315. https://doi.org/http://dx.doi.org/10.23887/jipp.v3i3.21840

Madroji, Zulaiha, F., \& Faizah. (2019). Pengembangan Modul Fisika Berbasis Problem Based Learning pada Materi Fluida Dinamis untuk Meningkatkan Kemampuan Berpikir Kritis Siswa 
Kelas XI SMAN 1 Astanajapura. Jurnal Pendidikan Fisika Dan Sains, 2(1), 17-23.

Maiyana, E. (2018). Pemanfaatan Android dalam Perancangan Aplikasi Kumpulan Doa. Jurnal Sains Dan Informatika, 4(1), 54-67.

Mardhiyah, R. H., Aldriani, S. N. F., Chitta, F., \& Zulfikar, M. R. (2021). Pentingnya Keterampilan Belajar di Abad 21 sebagai Tuntutan dalam Pengembangan Sumber Daya Manusia. Lectura: Jurnal Pendidikan, 12(1), 29-40. https://doi.org/10.31849/lectura.v12i1.5813

Maulida, L. (2020). APJII: Pengguna Internet Indonesia Hampir Capai 200 juta. Tersedia pada https://www.tek.id/tek/apjii-pengguna-internet-indonesia-hampir-capai-200-juta-b1ZWK9jo8. Diakses pada tanggal 27 April 2021.

Mulyatiningsih, E. (2008). Pengembangan Model Pembelajaran. Yogyakarta: Univeristas Negeri Yogyakarta.

Novtiar, C., \& Aripin, U. (2017). Meningkatkan Kemampuan Berpikir Kritis Matematis dan Kepercayaan Diri Siswa SMP melalui Pendekatan Open Ended. Jurnal Prisma Universitas Suryakencana, 6(2), 119-131. https://doi.org/10.35194/jp.v6i2.122

Oktavia, B., Zainul, R., Guspatni, \& Putra, A. (n.d.). Pengenalan dan Pengembangan E-Modul Bagi Guru-Guru Anggota MGMP Kimia dan Biologi Kota Padang Panjang. https://doi.org/10.31227/osf.io/yhau2

Pamungkas, R. A. (2020). Pengembangan Media Pembelajaran Menggunakan Kodular pada Materi Percabangan dan Perulangan guna Meningkatkan Pemahaman Siswa. In Skripsi. Fakultas Keguruan dan Ilmu Pendidikan. Surakarta: Universitas Muhammadiyah Surakarta.

Prabowo, C. A., Ibrohim, \& Saptasari, M. (2016). Pengembangan Modul Pembelajaran Inkuiri Berbasis Laboratorium Virtual. Jurnal Pendidikan - Teori, Penelitian, Dan Pengembangan, 1(6), 1090-1097. https://doi.org/10.17977/jp.v1i6.6422

Puspitasari, A. D. (2019). Penerapan Media Pembelajaran Fisika Menggunakan Modul Cetak dan Modul Elektronik pada Siswa SMA. Jurnal Pendidikan Fisika, 7(1), 17-25.

Ratnawati, D., Handayani, I., \& Hadi, W. (2020). Pengaruh Model Pembelajaran PBL Berbantu Question Card terhadap Kemampuan Berpikir Kritis Matematis Siswa SMP. Edumatica: Jurnal Pendidikan Matematika, 10(1), 44-51. https://doi.org/10.22437/edumatica.v10i01.7683

Ronaldo, R., \& Ardoni, A. (2020). Pembuatan Aplikasi Mobile "Wonderful of Minangkabau" sebagai Gudang Informasi Pariwisata di Sumatera Barat Melalui Website Kodular. Info Bibliotheca: Jurnal Perpustakaan Dan Ilmu Informasi, 2(1), 88-93. https://doi.org/10.24036/ib.v2i1.90

Santosa, A. S. E., Santyadiputra, G. S., \& Divayana, D. G. H. (2017). Pengembangan E-Modul Berbasis Model Pembelajaran Problem Based Learning pada Mata Pelajaran Administrasi Jaringan Kelas XII Teknik Komputer dan Jaringan di SMK TI Bali Global Singaraja. Kumpulan Artikel Mahasiswa Pendidikan Teknik Informatika (KARMAPATI), 6(1), 62-72. https://doi.org/10.23887/karmapati.v6i1.9269

Sari, P. (2015). Memotivasi Belajar dengan Menggunakan E-Learning. Jurnal Ummul Quro, 6(2), 20 
35.

Sari, R. N. (2019). Analisis Kemampuan Berpikir Kritis Matematik dengan Menggunakan Graded Response Models (GRM). In Skripsi. Fakultas Tarbiyah dan Keguruan. Lampung: Universitas Negeri Raden Intan.

Satriawati, H. (2015). Pengembangan E-Modul Interaktif sebagai Sumber Belajar Elektronika Dasar Kelas X SMKN 3 Yogyakarta. In Skripsi. Fakultas Teknik. Yogyakarta: Universitas Negeri Yogyakarta.

Siamy, L., Farida, \& Syazali, M. (2018). Media Belajar Matematika Berbasis Multimedia Interaktif dengan Pendekatan Contextual Teaching and Learning. Desimal: Jurnal Matematika, 1(1), 113117. https://doi.org/10.24042/djm.v1i1.1919

Suarsana, I. M., \& Mahayukti, G. A. (2013). Pengembangan E-Modul Berorientasi Pemecahan Masalah untuk Meningkatkan Keterampilan Berpikir Kritis Matematika. Jurnal Nasional Pendidikan Teknik Informatika (JANAPATI), 2(3), 264-275. https://doi.org/10.23887/janapati.v2i3.9800

Sugiyono. (2016). Metode Penelitian Kuantitatif Kualitatif dan R\&D. Bandung: Alfabeta.

Sulisworo, D., Jauhari, I., \& Firdausy, K. (2014). Pengembangan Sistem Manajemen Pembelajaran Kooperatif Secara Mobile Berbasis Sistem Operasi Android. Indonesian Jurnal of Curriculum and Educational Technology Studies, 3(1), 56-62.

Sumiati, A., \& Agustini, Y. (2020). Analisis Kesalahan Siswa SMP Kelas VIII dalam Menyelesaikan Soal Segitiga dan Segiempat. Jurnal Cendekia: Jurnal Pendidikan Matematika, 4(1), 321-330. https://doi.org/10.25157/teorema.v5i2.3070

Syarisma, N. F. (2020). Pengembangan Media Pembelajaran Berbasis Android Berbantu Aplikasi Appypie Pembelajaran Fluida. In Skripsi. Fakultas Tarbiyah dan Keguruan. Makassar: UIN Alauddin Makassar.

Tsai, T. P., Lin, J., \& Lin, L. C. (2018). A Flip Blended Learning Approach for ePUB3 eBook-Based Course Design and Implementation. Eurasia Journal of Mathematics, Science and Technology Education, 14(1), 123-144. https://doi.org/10.12973/ejmste/79629

Widoyoko, E. P. (2014). Evaluasic Program Pembelajaran. Yogyakarta: Pustaka Pelajar.

Widoyoko, E. P. (2015). Penilaian Hasil Pembelajaran di Sekolah. Yogyakarta: Pustaka Pelajar.

Zulfa, N. I. (2019). Pengembangan Modul Matematika Berbasis Guided Inquiry untuk Meningkatkan Kemampuan Berpikir Kritis. In Skripsi. Bandung: Universitas Islam Negeri Walisongo. 